\title{
Hubungan antara Kadar Vitamin D dan Derajat Keparahan Dermatitis Atopik
}

\author{
Ahimsa Yoga Anindita, Ganung Harsono, Endang Dewi Lestari \\ Departemen Ilmu Kesehatan Anak Fakultas Kedokteran Universitas Sebelas Maret, Surakarta
}

\begin{abstract}
Latar belakang. Dermatitis atopik adalah penyakit kulit kronik yang sering ditemukan pada anak. Prevalensi DA anak antara 10\%$20 \%$. Kondisi defisiensi vitamin D dikhawatirkan dapat memperburuk kondisi dermatitis atopik. Perkembangan penyakit menjadi lebih progresif, penyembuhan lama, dan risiko infeksi sekunder menjadi lebih besar. Hingga saat ini masih terdapat perbedaan hasil penelitian mengenai hubungan kadar vitamin D dan derajat keparahan dermatitis atopik.

Tujuan. Mengetahui hubungan kadar vitamin D dengan derajat keparahan dermatitis atopik.

Metode. Penelitian ini merupakan penelitian observasional analitik dengan menggunakan studi potong lintang. Subjek penelitian merupakan pasien anak berusia 2 sampai 5 tahun dengan DA di RS Dr. Moewardi Surakarta antara bulan Januari sampai Oktober 2018. Pengambilan sampel secara konsekutif berjumlah 24 sampel. Setiap subjek diukur kadar vitamin D serum dan diperiksa derajat keparahan dermatitis atopik. Hubungan antarvariabel dianalisis menggunakan Spearman rank untuk memperoleh koefisien korelasi. Hasil bermakna jika $\mathrm{p} \leq 0,05$.

Hasil. Terdapat hubungan signifikan antara kadar vitamin D dan derajat keparahan DA $(r=0,936 ; p=0,000)$. Hubungan ini sangat kuat dan berkorelasi positif.

Kesimpulan. Semakin rendah kadar vitamin D serum maka semakin berat derajat keparahan DA pada anak usia 2 sampai 5 tahun. Sari Pediatri 2019;20(5):265-9
\end{abstract}

Kata kunci: hubungan, kadar vitamin D, derajat keparahan dermatitis atopik, anak

\section{The Relationship between Vitamin D Levels and The Severity of Atopic Dermatitis}

Ahimsa Yoga Anindita, Ganung Harsono, Endang Dewi Lestari

Background. Atopic dermatitis is a chronic skin disease, commonly found in children. The prevalence is $10-20 \%$ in childhood. Vitamin D deficiency is thought to worsen atopic dermatitis. The disease becomes more progressive, longer healing, and greater risk of secondary infection. Until now, there are still differences in the results of studies regarding the relationship between vitamin D levels and the severity of atopic dermatitis.

Objective. This study aimed to determine the relationship between vitamin D levels and the severity of atopic dermatitis.

Methods. This study was an observational analytic study using cross-sectional. The study subjects were patients aged 2 to 5 years with atopic dermatitis in Dr. Moewardi Hospital Surakarta between January and October 2018. Consecutive samples were 24. Each subject was measured serum vitamin D levels and examined the severity of atopic dermatitis. The relationship between variables was analyzed using Spearman rank to obtain correlation coefficients. It was statistically significant if $\mathrm{p} \leq 0,05$.

Result. There was a significant relationship between vitamin D levels and the severity of atopic dermatitis $(r=0.936 ; \mathrm{p}=0,000)$. This relationship was very strong and positively correlated.

Conclusion. The lower the serum vitamin D levels, the more severe the severity of atopic dermatitis in children aged 2 to 5 years. Sari Pediatri 2019;20(5):265-9

Keywords: relationship, vitamin D levels, the severity of atopic dermatitis, children

Alamat korespondensi: Ahimsa Yoga Anindita. Departemen Ilmu Kesehatan Anak Fakultas Kedokteran Universitas Sebelas Maret, Surakarta. Email: ahimsanindita@gmail.com 
Ahimsa Yoga Anindita dkk: Hubungan antara kadar vitamin D dan derajat keparahan dermatitis atopik

$\mathrm{D}$ ermatitis atopik (DA) adalah penyakit kulit kronik yang sering ditemukan pada anak. Prevalensi DA anak antara 10\%-20\%, sedangkan dewasa $1 \%-3 \%$ di seluruh dunia. ${ }^{1}$ Penyakit kulit ini disebabkan oleh adanya inflamasi multifaktorial yang berakibat adanya interaksi antara kerentanan genetik dan faktor lingkungan. ${ }^{2}$ Patogenesis pasti DA saat ini masih sedikit dipahami, dan kesulitan terapi juga masih menjadi tantangan tersendiri. Saat ini terdapat bukti-bukti adanya polimorfisme gen baru yang berhubungan dengan fungsi pertahanan epidermis dan imunitas adaptif dan bawaan mendasari patomekanisme DA. ${ }^{2,3}$

Gejala khas dari DA adalah peradangan kulit kronis, berulang, disertai rasa gatal, kulit kering, timbul di tempat predileksi tertentu, sering terjadi pada masa awal bayi dan anak usia dini, dan mungkin bisa terjadi remisi pada masa dewasa. ${ }^{4}$ Gangguan fungsi sawar kulit, gangguan sistem imun, genetik, dan faktor-faktor lain, termasuk lingkungan, diet, infeksi, dan stres berperan dalam derajat beratnya gejala klinis DA. Gangguan fungsi sawar menyebabkan mudahnya kolonisasi dan infeksi bakteri ke kulit, terutama Staphylococcus aureus. Infeksi sekunder ini akan menyebabkan aktivasi sel $\mathrm{T}$ dan sel imun lainnya. ${ }^{3,5}$

Kadar vitamin D dalam tubuh ikut berperan dalam proses imunologi yang berlangsung pada DA. Secara umum, vitamin D adalah sebuah hormon pleiotropik pada jaringan tubuh manusia dengan mengatur homeostasis mineral dan imunitas. Vitamin D bersifat sebagai imunomodulator. Vitamin D akan membantu meningkatkan integritas permeabilitas sawar kulit, penghambatan infeksi sekunder, dan menekan respons inflamasi. ${ }^{6}$ Kadar vitamin D dalam tubuh akan memengaruhi derajat imunitas seseorang, begitu juga akan memengaruhi insiden dan derajat keparahan DA. ${ }^{7}$ Kondisi defisiensi vitamin D dipikirkan dapat memperburuk kondisi DA. Perkembangan penyakit menjadi lebih progresif, penyembuhan lama, dan risiko infeksi sekunder menjadi lebih besar. Pada penelitian in vitro, vitamin $\mathrm{D}$ memiliki manfaat untuk meningkatkan ekspresi cathelicidin dan aktivitas antimikroba dalam keratinosit yang akan membantu mengembalikan integritas sawar epidermal yang efektif. ${ }^{6,8}$

Beberapa penelitian mengemukakan hubungan kadar vitamin D pada anak dengan DA. Salah satunya, anak dengan DA memiliki kadar vitamin D yang lebih rendah. ${ }^{9}$ Terdapat keterkaitan kadar vitamin D terhadap derajat keparahan DA secara signifikan. ${ }^{10,11}$ Berbeda dengan hasil penelitian lain yang menyatakan bahwa tidak ada korelasi yang signifikan antara kadar vitamin D dengan derajat keparahan DA. ${ }^{12,13}$ Perbedaan hasil inilah yang mendorong peneliti untuk meneliti hal tersebut.

\section{Metode}

Penelitian ini adalah penelitian observasional analitik dengan studi potong lintang yang dilakukan di RS Dr. Moewardi Surakarta dari bulan Januari sampai dengan Oktober 2018. Sampel penelitian adalah pasien yang datang dan memenuhi kriteria inklusi serta tidak memenuhi kriteria eksklusi sampai besar sampel minimal terpenuhi. Sebelumnya, orangtua/ wali menandatangani lembar persetujuan mengikuti penelitian. Kriteria inklusi, antara lain, terdiagnosis DA melalui kriteria klinis oleh dokter, anak yang berusia 2 sampai dengan 5 tahun, dan pasien DA dengan status gizi baik, berat badan, tinggi badan normal menurut usia (berat badan berdasar tinggi badan berada pada atau di antara -2 SD dan +2 SD berdasarkan grafik WHO). Kriteria eksklusi, antara lain, pasien yang memperoleh suplementasi vitamin D sebelumnya, memperoleh pengobatan kortikosteroid oral dalam 2 minggu, dan terdapat kelainan yang dapat menjadi faktor risiko terhadap kejadian defisiensi vitamin D, seperti gangguan fungsi ginjal (laju filtrasi glomerulus $\leq 90 \mathrm{ml} / \mathrm{menit} / 1,73 \mathrm{~m}^{2}$ ) dan liver (kenaikan alanin transaminase dan/atau aspartat transaminase $\geq 2 \mathrm{kali}$ nilai normal).

Koefisien korelasi minimal yang dianggap bermakna ditetapkan sebesar $0,5 .{ }^{14}$ Berdasarkan perhitungan dan tabel besar sampel untuk analitik korelatif ordinal diperoleh jumlah subjek yang diperlukan adalah 24. Kadar vitamin D diperoleh dari pengukuran di laboratorium klinik dengan sampel darah vena. Vitamin D yang diukur adalah vitamin D total atau disebut dengan $25(\mathrm{OH}) \mathrm{D}$, dinyatakan dengan satuan $\mathrm{ng} / \mathrm{ml}$. Kemudian akan dikelompokkan menjadi normal jika lebih dari $20 \mathrm{ng} / \mathrm{ml}$ sampai dengan $100 \mathrm{ng} / \mathrm{ml}$, defisiensi ringan jika berada pada rentang $12 \mathrm{ng} / \mathrm{ml}$ sampai dengan $20 \mathrm{ng} / \mathrm{ml}$, defisiensi sedang jika berada pada rentang $5 \mathrm{ng} / \mathrm{ml}$ sampai dengan kurang dari $12 \mathrm{ng} / \mathrm{ml}$, dan defisiensi berat jika kurang dari $5 \mathrm{ng} / \mathrm{ml} .{ }^{15}$ Derajat keparahan DA dinilai melalui sistem skoring menggunakan scoring atopic 
dermatitis (SCORAD). Penilaian SCORAD diambil dari 3 bagian besar, yaitu luas area yang terlibat DA, nilai keparahan kondisi pada kulit DA, dan nilai gejala gatal dan gangguan tidur pada pasien DA. Nilai total akan dikelompokkan menjadi 3 kriteria, yaitu DA derajat ringan (SCORAD <25), sedang (SCORAD di antara 25 dan 50), dan berat (SCORAD > 50). ${ }^{16,17}$ Hubungan bivariat antara kedua variabel dianalisis dengan Spearman rank menggunakan program SPSS. Hasil disebut bermakna jika $p \leq 0,05$. Penelitian ini sudah memperoleh kelaikan etik dan dinyatakan layak etik oleh Komisi Etik Penelitian Kesehatan RS Dr. Moewardi/Fakultas Kedokteran Universitas Sebelas Maret.

\section{Hasil}

Penelitian ini dilakukan pada 24 pasien DA yang berusia 2 sampai dengan 5 tahun yang berada di RS Dr. Moewardi Surakarta antara bulan Januari 2018 sampai dengan Oktober 2018. Karakteristik demografi subjek penelitian tertera pada Tabel 1 .

Berdasarkan Tabel 1, mayoritas pasien berjenis kelamin lelaki 13 pasien $(54,2 \%)$, sedangkan sisanya berjenis kelamin perempuan 11 pasien $(45,8 \%)$. Mayoritas pasien berusia $>3-4$ tahun 11 pasien $(45,8 \%)$, sedangkan minoritas berusia $>4-5$ tahun ada 6 pasien $(25,0 \%)$. Mayoritas pasien dengan vitamin D dalam kategori defisiensi ringan 13 pasien $(54,2 \%)$,

Tabel 1. Karakteristik demografi subjek penelitian

\begin{tabular}{lcc}
\hline Variabel & Frekuensi & Persentase \\
\hline Jenis kelamin & & \\
$\quad$ Lelaki & 13 & 54,2 \\
Perempuan & 11 & 45,8 \\
Usia (tahun) & & \\
$2-3$ & 7 & 29.2 \\
$>3-4$ & 11 & 45,8 \\
$>4-5$ & 6 & 25,0 \\
Kadar vitamin D & & \\
Normal & 2 & 8,3 \\
Defisiensi ringan & 13 & 54,2 \\
Defisiensi sedang & 8 & 33,3 \\
$\quad$ Defisiensi berat & 1 & 4,2 \\
Derajat keparahan DA & & \\
$\quad$ Ringan & 15 & 62,5 \\
Sedang & 7 & 29,2 \\
Berat & 2 & 8,3 \\
\hline
\end{tabular}

Tabel 2. Hubungan kadar vitamin D dengan derajat keparahan DA

\begin{tabular}{|c|c|c|c|c|c|c|}
\hline \multirow[t]{2}{*}{ Kadar vitamin D } & \multicolumn{3}{|c|}{ Derajat DA } & \multirow[t]{2}{*}{ Total } & \multirow[t]{2}{*}{$\mathrm{r}$} & \multirow[t]{2}{*}{$\mathrm{p}$} \\
\hline & Ringan & Sedang & Berat & & & \\
\hline \multirow[t]{2}{*}{ Normal } & 2 & 0 & 0 & 2 & 0,936 & 0,000 \\
\hline & $100,0 \%$ & $0,0 \%$ & $0,0 \%$ & $100,0 \%$ & & \\
\hline \multirow[t]{2}{*}{ Ringan } & 13 & 0 & 0 & 13 & & \\
\hline & $100,0 \%$ & $0,0 \%$ & $0,0 \%$ & $100,0 \%$ & & \\
\hline \multirow[t]{2}{*}{ Sedang } & 0 & 7 & 1 & 8 & & \\
\hline & $0,0 \%$ & $87,5 \%$ & $12,5 \%$ & $100,0 \%$ & & \\
\hline \multirow[t]{2}{*}{ Berat } & 0 & 0 & 1 & 1 & & \\
\hline & $0,0 \%$ & $0,0 \%$ & $100,0 \%$ & $100,0 \%$ & & \\
\hline \multirow[t]{2}{*}{ Total } & 15 & 7 & 2 & 24 & & \\
\hline & $62,5 \%$ & $29,2 \%$ & $8,3 \%$ & $100,0 \%$ & & \\
\hline
\end{tabular}


sedangkan minoritas vitamin D dalam kategori defisiensi berat 1 pasien (4,2\%). Mayoritas pasien dengan derajat keparahan DA dalam kategori ringan 15 pasien $(62,5 \%)$, sedangkan minoritasdengan derajat keparahan DA kategori berat 2 pasien $(8,3 \%)$.

Hubungan defisiensi vitamin $\mathrm{D}$ dengan derajat keparahan DA dianalisis menggunakan uji spearman rank.

Hasil uji spearman rank didapatkan nilai $\mathrm{r}=0,936$ dan nilai $\mathrm{p}=0,000(\mathrm{p}<0,05)$ yang berarti bahwa terdapat hubungan yang positif dan signifikan antara defisiensi vitamin D dengan derajat keparahan dermatitis atopik. Kekuatan hubungan tersebut dalam kategori sangat kuat.

\section{Pembahasan}

Berdasarkan penelitian yang telah dilakukan ini, memang DA lebih banyak terdapat pada pasien lelaki dibandingkan perempuan. Hal ini dimungkinkan karena aktivitas fisik anak lelaki lebih banyak sehingga risiko kerusakan barrier kulit pada anak lelaki lebih besar dibandingkan anak perempuan. ${ }^{4}$ Namun, perbedaan jumlah antara lelaki dan perempuan tidak terlalu bermakna. Sesuai dengan kepustakaan sebelumnya bahwa perbandingan antara jumlah lelaki dan perempuan tergantung pada studi yang dilakukan. Pada studi ini lebih banyak lelaki sesuai dengan studi di India. ${ }^{18}$ Persentase pasien dengan DA berjenis kelamin lelaki dan perempuan pada studi ini berturut-turut adalah $54,2 \%$ dan $45,8 \%$. $\mathrm{Hal}$ ini hampir mirip dengan persentase penelitian yang dilakukan di poliklinik rawat jalan RSUD Dr. Soetomo Surabaya pada tahun 2007 sampai dengan 2011, yaitu berturut-turut 53,4\% dan 46,6\% untuk lelaki dan perempuan. ${ }^{19}$

Pemilihan usia untuk subjek penelitian DA diseragamkan agar mempermudah skoring. Selain itu pemilihan usia 2 sampai 5 tahun ditujukan berdasarkan penelitian sebelumnya bahwa onset DA paling sering pada usia 2 tahun dan hanya sedikit yang terdiagnosis setelah usia 5 tahun karena bentuk DA tipe childhood paling banyak terjadi. ${ }^{4,18,19}$ Pada studi ini juga sesuai dengan studi yang telah dilakukan sebelumnya bahwa paling banyak subjek penelitian mengalami DA derajat ringan $(62,5 \%)$ diikuti derajat sedang $(29,2 \%)$ dan berat $(8,3 \%) .^{4,18,20}$ Hampir seluruh pasien yang mengalami DA mengalami penurunan kadar vitamin D total. Hanya $2(8,3 \%)$ dari 24 pasien DA yang memiliki kadar vitamin D total normal. Sesuai dengan teori-teori yang telah diungkapkan sebelumnya bahwa memang pasien dengan DA akan mengalami penurunan vitamin D total oleh karena ketidakmampuan kulit (keratinosit utamanya) dalam mensintesis vitamin $\mathrm{D}$ aktif. Penurunan vitamin D serum juga berpengaruh pada integritas kulit yang berakibat pada lamanya proses penyembuhan DA dan komplikasi yang semakin beragam. ${ }^{21}$

Penelitian sebelumnya melaporkan bahwa terdapat hubungan yang bermakna antara derajat keparahan DA atopik dengan kadar vitamin D. ${ }^{10,11}$ Namun, ada pula yang mengungkapkan bahwa hubungan antara dua variabel tersebut tidak bermakna. ${ }^{12,13}$ Hasil studi kami menghasilkan korelasi positif antara derajat keparahan DA dengan kadar vitamin D total serum. Berdasarkan hasil analisis dengan spearman rank juga diperoleh hubungan yang positif dan bermakna antara defisiensi vitamin D dengan derajat keparahan dermatitis atopik. Hasil tersebut sesuai dengan penelitian yang telah dilakukan oleh Peroni $\mathrm{dkk}^{14}$ bahwa semakin rendah kadar vitamin D tubuh, pertahanan barrier kulit semakin rendah, semakin berat pula nilai SCORAD yang diperoleh..$^{9-11}$

Kelemahan penelitian ini adalah adanya variabel perancu yang belum dapat sepenuhnya dikendalikan, yaitu aktivitas fisik dan frekuensi paparan sinar matahari. Pengendalian variabel perancu hanya sebatas pada usia subjek penelitian 2 sampai dengan 5 tahun di Surakarta. Hal ini diasumsikan bahwa kelompok anak usia 2 sampai dengan 5 tahun termasuk preschool children yang memiliki aktivitas fisik hampir sama dan tinggal di Surakarta sehingga frekuensi paparan sinar matahari juga hampir sama. Serta tidak dilakukannya analisis diet secara detail sehingga tidak diketahui berapa besarnya asupan vitamin D yang diperoleh dari makanan. Kelemahan lain adalah jumlah sampel yang sangat terbatas, yaitu hanya 24 subjek penelitian sesuai perhitungan sampel minimal. Selain itu tidak dilakukannya pemeriksaan lengkap terhadap fungsi liver lain (jumlah trombosit, kadar albumin, gammaglutamyl transferase, dan alkali fosfatase) pada kriteria eksklusi karena keterbatasan biaya penelitian dan tidak diperhatikannya pengaruh epigenetik pada subjek penelitian yang turut berpengaruh terhadap derajat keparahan DA, termasuk dalam kelemahan penelitian ini. 


\section{Kesimpulan}

Didapatkan hubungan antara kadar vitamin D dan derajat keparahan DA. Semakin rendah kadar vitamin D maka semakin berat derajat keparahan DA pada anak.

\section{Daftar pustaka}

1. Mesquita KC, Igreja ACSM, Costa IMC. Atopic dermatitis and vitamin D: facts and controversies. An Bras Dermatol 2013;88:945-53.

2. Abramovits W. Atopic dermatitis. J Am Acad Dermatol 2005;53:86-93.

3. Reich K, Westphal G, Konig IR, Mossner R, Schupp P, Gutgesell C, dkk. Cytokine gene polymorphisms in atopic dermatitis. Br J Dermatol 2003;148:1237-41.

4. Lyons JJ, Milner JD, Stone KD. Atopic dermatitis in children: clinical features, pathophysiology and treatment. Immunol Allergy Clin North Am 2015;35:161-83.

5. Cork MJ, Danby SG, Vasilopoulos Y, Hadgraft J, Lane ME, Moustafa M, dkk. Epidermal barrier dysfunction in atopic dermatitis. J Invest Dermatol 2009;129:1892-908.

6. Myszka M, Klinger M. The immunomodulatory role of vitamin D. Postepy Hig Med Dosw 2014;68:865-78.

7. Searing DA, Leung DYM. Vitamin D in atopic dermatitis, asthma and allergic diseases Immunol Allergy Clin North Am 2010;30:397-409 doi: 10.1016/j.iac.2010.05.005.

8. Hata TR, Kotol P, Jackson M, Nguyen M, Paik A, Udal D, dkk. Administration of oral vitamin D induces cathelicidin production in atopic individuals. J Allergy Clin Immunol 2008;22:829-31.

9. Widyaswari MS, Zulkarnain I, Indramaya DM. 2016. Kadar serum vitamin D (25[OH]D) pada pasien dermatitis atopik. Berkala Ilmu Kesehatan Kulit dan Kelamin 2016;28:10-7.

10. Munawwarah L, Evalina R, Sofyani S, Irsa L, Lubis M. Hubungan kadar 25-Hydroxyvitamin-D dengan indeks scoring of atopic dermatitis pada anak dermatitis atopik [tesis]. Medan: Universitas Sumatera Utara; 2016.

11. Su O, Bahali AG, Demir AD, Ozkaya DB, Uzuner S, Dizman $\mathrm{D}$, dkk. The relationship between severity of disease and vitamin $\mathrm{D}$ levels in children with atopic dermatitis. Adv Dermatol Allergol 2017;34:224-7.

12. Robl R, Uber M, Abbage KT, Lima MN, Carvalho VO. Serum vitamin D level not associated with atopic dermatitis severity. Pediatr Dermatol 2016;33:283-8.

13. Yurmalina. Hubungan kadar 25-Hydroxyvitamin D dengan kejadian dan derajat keparahan dermatitis atopik pada anak [tesis]. Padang: Universitas Andalas; 2015.

14. Peroni DG, Piacentini GL, Cametti E, Chinellato I, Boner AL. Corellation between serum 25-hydroxyvitamin D level and severity of atopic dermatitis in children. Br J Dermatol2011;164:1078-82.

15. The Royal Children's Hospital Melbourne. Vitamin D deficiency. 2012.Diakses tanggal 6 Agustus 2017. Didapat dari: http://www.rch.org.au/clinicalguide/guideline_index/ Vitamin_D_deficiency/

16. Stalder JF, Taieb A, Atherton DJ, Bieber T, Bonifazi E, Broberg A, dkk. Severity scoring of atopic dermatitis: the SCORAD index, consensus report of the european task force on atopic dermatitis. Int J Clin Investig Dermatol 1993;186:23-31.

17. Acton QA. Atopic dermatitis: new insights for the healthcare professional. Edisi pertama. Georgia: Scholarly Editions; 2013.h.2-5.

18. Nutten S. Atopic dermatitis: global epidemiology and risk factors. Ann Nutr Metab 2015;66:8-16.

19. Sihaloho K, Indramaya DM. Penelitian retrospektif: dermatitis atopik pada anak. Berkala Ilmu Kesehatan Kulit dan Kelamin 2015;27:176-82.

20. Thomsen SF. Atopic dermatitis: natural history, diagnosis, and treatment. ISRN Allergy 2014;2014:1-7.

21. Sinantryana M, Widyaswari, Zulkarnain I, Indramaya DM. Kadar serum vitamin D (25[OH]D) pada pasien dermatitis atopik. Berkala Ilmu Kesehatan Kulit dan Kelamin 2016;28:10-7. 